\title{
COMPARATIVE INVESTIGATIONS INTO ENERGETIC AND ECOLOGICAL PARAMETERS OF CAMELINA-BASED BIOFUEL USED IN THE 1Z DIESEL ENGINE
}

\author{
Sergejus Lebedevass ${ }^{1}$, Saugirdas Pukalskas ${ }^{2}$, Justas Žaglinskiss ${ }^{3}$, Jonas Matijošius ${ }^{4}$ \\ ${ }^{1,3}$ Dept of Marine Engineering, Klaipeda University Maritime Institute, \\ I. Kanto g. 7, LT-92123 Klaipeda, Lithuania \\ ${ }^{2,4}$ Dept of Automobile Transport, Vilnius Gediminas Technical University, \\ J. Basanavičiaus g. 28, LT-03224 Vilnius, Lithuania \\ E-mails: ${ }^{1}$ sergejus.lebedevas@ku.lt; ${ }^{2}$ saugirdas.pukalskas@vgtu.lt (corresponding author); \\ 3j.zaglinskis@gmail.com; ${ }^{4}$ jonas.matijosius@vgtu.lt
}

Submitted 14 February 2012; accepted 2 May 2012

\begin{abstract}
The paper presents the findings of comparative investigations into the operation of Audi 801.914 cylinder diesel engine, TDI, type 1Z, $66 \mathrm{~kW}$ powered by new FAME (fatty acid methyl esters) mixtures of spring (SCME) and winter (WCME) camelina-based biofuel and mineral diesel. The article assesses the principles of operating electronic control over the diesel engine (ECS) and exhaust gas recirculation (EGR) and looks at a positive impact of the system on energetic $\left(\mathrm{b}_{\mathrm{e}}, \eta_{\mathrm{e}}\right)$ and ecological $\left(\mathrm{CH}, \mathrm{NO}_{\mathrm{x}}, \mathrm{CO}_{2}, \mathrm{SM}\right)$ parameters. The ECS of the average and maximal power of the engine improve in-cylinder air injection that has an impact on an increase in $\eta_{\mathrm{e}}$ by approximately $30 \%$ and reduces the emission of the harmful components from incomplete combustion. It is accepted that in case diesel fuel is replaced by FAME biofuels (RME - rapeseed methyl ester; SCME - spring camelina methyl ester; WCME - winter camelina methyl ester), ECS control parameters shall not be retrofitted or additionally optimized. The properties of camelina-based biofuel mixtures B30 (SCME) and B30 (WCME) and diesel fuel are similar to the properties of the standard mixtures of RME biofuel B30 (RME). If compared to diesel fuel, the use of camelina-based biofuel mixtures B30 (SCME) and B30 (WCME) enables lower emissions of harmful components from exhaust gases, which makes approximately $15 \%$ of $\mathrm{CH}$ and $20 \div 25 \%$ of SM.
\end{abstract}

Keywords: vehicle diesel engine, camelina sativa, biofuels, ecological parameters, energetic parameters.

\section{Introduction}

One of the most important strategic aims of the European Union policy is environmental protection. According to the EU Agreement, the economic development policy of the Member States must be based on environmental protection criteria. Recently, careful attention has been paid to reducing greenhouse gas emissions. The regulation started working in 1992 according to the United Nations Framework Convention on Climate Change. In 1997, the Kyoto Protocol that encouraged lowering greenhouse gas emissions was signed. Transport and energy using fossil fuel are the main sources of atmospheric pollution; therefore, the EU documents suggest replacing mineral fuel by renewable energy sources thus increasing their application in various economic areas (European Commission 2011).

Another reason for an increase in the use of biofuels is insufficient (first of all, in Europe) potential for raw materials of RME as well as moral and political aspects of fuel production from feedstock. In the last decade, a number of investigations into food safety and changes in land use related to the production of biofuels have been conducted. Food prices, including rapeseed, considerably increased in 2007 and 2008. One of the reasons for such appreciation is the use of the raw materials of food origin in the production of biofuels. However, a rise in food prices could be explained by various reasons, for example, by 'rising energy costs, climate change, stagnation in crop productivity and diversion of crops or croplands to biofuel production' (Koh, Ghazoul 2008). Moreover, an increase in food prices may be useful to farmers (Goldemberg, Guardabassi 2009), but make harm to the poor residents of the city. Due to the raising value of biofuels and raw materials, farmers all over the world turn forests and grassland into agricultural land to increase crops. Searchinger et al. (2008) and Fargione 
et al. (2008) state that turning carbon rich forest areas into agricultural land inevitably increases the amount of $\mathrm{CO}_{2}$ emissions into the atmosphere. During this process, the amount of greenhouse gas emissions increases considerably rather than they may be reduced when fossil fuels are replaced by biofuels, i.e. the use of biofuels along with changes in the use of land indirectly influences an increasing amount of greenhouse gas emissions. With reference to the above information it can be stated that the long-term use of biofuels generated from traditional cultures and crops is not sustainable; therefore, biofuels should be produced from raw waste and/ or raw plants grown in degraded or abandoned lands.

One of possible solutions to the problem is the use of camelina-based biofuels complying with the requirements set to fatty acid methyl esters (FAME) that may grow in the environment mentioned above. Quite a few laboratory and motor tests were performed applying camelina-based methyl esters (Moser, Vaughn 2010; Fröhlich, Rice 2005; Wu, Leung 2011). Lithuanian scientific institutions (Lithuanian Institute of Agriculture of Aleksandras Stulginskis University, Klaipeda University) and their Polish partners have been successfully implementing the project EUREKA 'E!4018 CAMELINA-BIOFUEL' aimed at investigating the use of camelina sativa oil in the production of biofuels. The carried out project included the following stages of work: production technologies for new biofuels made from camelina sativa have been worked out and approved; requirements for biofuel standard LST EN 14214:2003 set to FAME biofuels have been fulfilled; a wide spectrum of comparative investigations into the use of biofuels and diesel fuel applied for stationary diesel engines have been conducted; stability parameters of the diesel engine running on rapeseed methyl ester and camelinabased methyl ester biofuels have been assessed and investigated.

The aim of the investigation stage described in this publication is the application of camelina-based biofuels for operating the vehicle's diesel engine. According to the data provided by the Department of Statistics of the Republic of Lithuania (http://www.stat.gov.lt) in 2010 , diesel engines used $67.7 \%$ of mineral fuels compared with the total amount of fuel used in the country. Meanwhile, the total balance of used fuel and biodiesel reached only $4 \%$. Therefore, the use of biofuels in diesel engines considering road transport is one of the most effective ways to reduce an environmental impact and to solve the issues related to Lithuania's obligations to the EU.

\section{Investigation Object and Methodology}

The selected investigation object was Audi 80 1.91 4-cycle (stroke) 4 cylinder diesel engine, TDI, type 1Z, 66 $\mathrm{kW}$ made in 1992 . The engine with an open combustion chamber in direct injection, containing a turbocompressor, an exhaust gas recirculation system and an electronic engine control unit was tested. The main technical data on the engine are presented in Table 1.
Table 1. Technical data on $1 \mathrm{Z}$ diesel engine

\begin{tabular}{ll}
\hline \multicolumn{1}{c}{ Parameter } & \multicolumn{1}{c}{ Value } \\
\hline Engine displacement $V_{h}, \mathrm{~cm}^{3}$ & 1896 \\
\hline Number of cylinders & 4 \\
\hline Compression ratio $\varepsilon$ & 19.5 \\
\hline Rated power $P_{e}, \mathrm{~kW}$ & $66\left(4000 \mathrm{~min}^{-1}\right)$ \\
\hline Rotation moment $M_{s}, \mathrm{Nm}$ & $180\left(2000 \div 2500 \mathrm{~min}^{-1}\right)$ \\
\hline Mean effective pressure $P_{m e}, \mathrm{MPa}$ & $1.19(180 \mathrm{Nm})$ \\
\hline Cylinder bore $D, \mathrm{~mm}$ & 79.5 \\
\hline Piston stroke $S, \mathrm{~mm}$ & 95.5 \\
\hline
\end{tabular}

Fig. 1 presents the scheme of $1 \mathrm{Z}$ diesel engine and equipment controlling and handling its work. Based on the operating mode of the engine, ambient air conditions and other parameters, an electronic control system (10) optimizes the cyclic amount of fuels and their injection phase. To reduce $\mathrm{NO}_{\mathrm{x}}$ pollution, the recirculation system of combustion products (17) was mounted. When the engine power increases, the EGR system reduces the recirculation degree of exhaust gases.

Engine test stand. Investigations into the automated mounted stand KI-5543 were conducted applying a weight dynamometer to identify the torque moment generated by the internal combustion engine.

An electric asynchronic engine with a wound rotor, liquid rheostat and dynamometer was used as the engine brake on the mounted universal stand. When diesel revolutions fall within the range of $600 \div 1400 \mathrm{~min}^{-1}$, the stand runs on electric engine resolutions, whereas when the resolutions fall within the range of $1600 \div 3000 \mathrm{~min}^{-1}$ it operates as a brake in the electric generator mode. The torque moment of the stand operating in the engine and

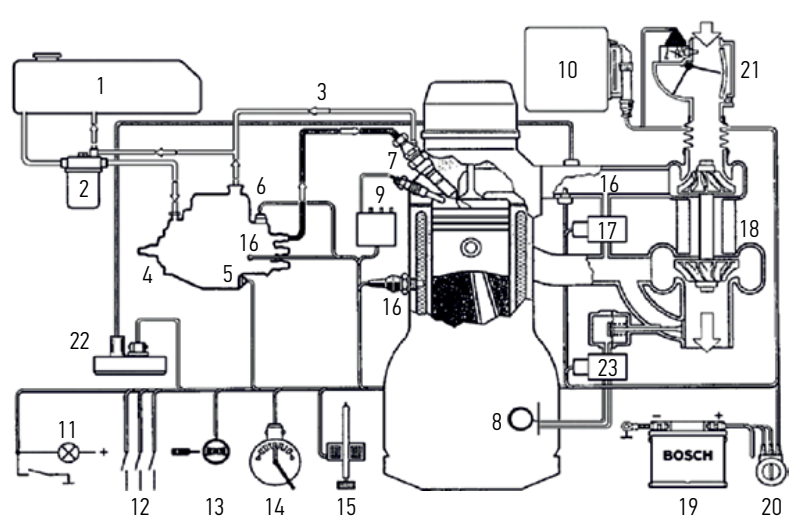

Fig. 1. Scheme of $1 Z$ TDI engine and its control system: 1 - fuel tank; 2 - fuel filter; 3 - feedback fuel line; 4 - high pressure fuel pump; 5 - injection phase corrector; 6 - fuel electromagnetic valve; 7 - nozzle with an injection duration sensor; 8 - vacuum pump; 9 - heating candle; 10 - ECS; 11 - diagnostic lamp; 12 - clutch, brake and engine brake switches; 13 - resolution and upper rest point sensor; 14 - accelerator potentiometer; 15 - speed sensor; 16 - temperature detectors; 17 - electropneumatic exhaust gas recirculation valve; 18 - turbocompressor; 19 - accumulator battery; 20 - starting switch; 21 - air debit gauge; 22 - sensor of pressure injection in the collector; 23 - turbocompressor control valve 
generator modes is controlled by the electromechanical drive liquid rheostat. The maximum stand braking moment reaches $186 \mathrm{Nm}$, and the maximum measured torque is $440 \mathrm{Nm}$. Torque measuring error makes up to $0.8 \%$ from the maximal value of the moment.

The engine is directly connected to the stand (without a gearbox) via shaft, both sides of which contain equal angular velocity joints.

Fuel consumption was measured employing electronic SK-5000 scales, the maximum limit of which makes 5000 and the value of mark $-1 \mathrm{~g}$. The accuracy of measuring fuel consumption per hour is $0.5 \%$.

To analyze the harmful components of exhaust gases from the engine, exhaust gas analyzer AVL DiCom 4000 was used. The measuring range and accuracy of the harmful components of the device in exhaust gases are presented in Table 2.

Table 2. The measuring range and accuracy of the device AVL DiCom 4000

\begin{tabular}{lll}
\hline & \multicolumn{1}{c}{ Measuring range } & Resolution \\
\hline $\begin{array}{lll}\text { Smokiness } \\
\quad \text { Smoke opacity }\end{array}$ & $0 \div 100 \%$ & $0.1 \%$ \\
$\quad$ Absorption $(K-$ factor) & $0 \div 99.99 \mathrm{~m}^{-1}$ & $0.01 \mathrm{~m}^{-1}$ \\
\hline Nitrogen oxides & $0 \div 5000 \mathrm{ppm}$ (vol.) & $1 \mathrm{ppm}$ \\
\hline Hydrocarbons & $0 \div 20000 \mathrm{ppm}$ (vol.) & $1 \mathrm{ppm}$ \\
\hline Carbon monoxide & $0 \div 10 \%$ (vol.) & $0.01 \%$ (vol.) \\
\hline Carbon dioxide & $0 \div 20 \%($ vol. $)$ & $0.1 \%$ (vol.) \\
\hline
\end{tabular}

The temperature of exhaust gases was measured in the following two ways:

- Infrared thermometer Emsitest IR 8839 was employed within the range of the measured temperature of $50 \div 1000^{\circ} \mathrm{C}$ under the limit of measurement error making $\pm 2^{\circ} \mathrm{C}$.

- Termophor TP-02A directly connected with the data registering measuring module Datalogger.

DL 2000 within the range of measured temperature from 0 to $650^{\circ} \mathrm{C}$ was applied.

The performed investigations have disclosed that the difference between the temperature values of exhaust gases measured in two ways does not exceed $\pm 10^{\circ} \mathrm{C}$.

When the engine is fuelled with diesel fuel, the values of excess-air ratio $\lambda$ are identified with reference to the device AVL DiCom 4000 based on the composition of exhaust gases.

Rapeseed oil methyl esters (RME) were purchased from biodiesel fuel producer JSC 'Mestilla' ( $h t t p: / / w w w$. mestilla.lt). The quality parameters of the esters met requirements for standard EN 14214:2003. Fossil diesel fuel was purchased from the market, and its quality parameters met requirements for standard EN 590:2004.

Camelina-based oil was obtained by mechanical pressing using laboratory press Skeepsta Maskin, type 40A. Oil transesterification with methanol was carried out using laboratory equipment and applying a conventional method of oil transesterification. Transesterification was accomplished at two stages. Pork lard methyl esters were produced from pork lard purchased from the market (Poland). Pork lard has a low iodine value (approximately $45 \mathrm{~g} \mathrm{I}_{2} / 100 \mathrm{~g}$ ). Scientists have determined that the mixtures containing $68 \%$ spring camelina-based oil and 32\% (vol.) of pork lard methyl esters meet requirements for standard EN 14214:2003.

Summer and winter camelina-based oil and pork lard methyl esters comply with requirements set for standard EN 14214:2003 and may be used in warm climate areas during the summer period. No considerable differences were established during the execution of the project between winter-type and summer-type camelina-based methyl esters.

The following types of fuel were used for investigation purposes:

- C class diesel fuel with a 5\% FAME additive complying with requirements for standard LST EN 590:2009+A1:2010.

- Winter and spring camelina-based biofuel mixtures complying with requirements for standard LST EN 14214:2003 containing 68\% of camelinabased methyl esters and 32\% (by volume) of pork lard methyl ester.

- Rapeseed methyl ester (RME) complying with requirements set for standard LST EN 14214:2003.

From an operational point of view, the low-temperature characteristic (CFPP) of biofuels is an important issue. In terms of CFPP, both WCME and SCME comply with requirements for standard LST EN 14214:2003 and can be used during warm seasons at temperatures higher than $-5.5^{\circ} \mathrm{C}$.

The following mixtures were tested during investigation:

- A mixture of rapeseed methyl ester and diesel fuel B30 (RME). The volumetric percent ratio of the mixture is D70/RME30.

- A mixture of winter camelina-based methyl ester and diesel fuel mixture B30 (WCME). The volumetric percent ratio of the mixture is D70/ WCME25/RME5.

- A mixture of spring camelina-based methyl ester and diesel fuel mixture B30 (SCME). The volumetric percent ratio of the mixture is D70/ SCME25/RME5.

To maintain the stability of thermal condition of the engine, its parameters were measured in $7 \div 10 \mathrm{~min}$ after identifying the work regime at the load of $n=2500 \mathrm{~min}^{-1}$ (maximal torque $M_{t \max }$ ).

To enhance the accuracy of measuring, the parameters were measured three times in each testing mode of the engine thus identifying the mean of the obtained data. To control the technical condition of the engine in the test start, run and finish, the parameters of the engine running on mineral diesel were registered.

\section{Research Findings}

The tests confirmed the technical condition of the diesel engine to be stable. Figs $2-5$ present the parameters of the engine running on diesel fuel (test start, run and finish). The dispersion of experimental data on excess-air 
ratio $\lambda$, the overall efficiency factor (OEF) $\eta_{e}$, smokiness $\mathrm{SM}$ and nitrogen oxides $\left(\mathrm{NO}_{\mathrm{x}}\right)$ emission from approximate curves is similar to the accuracy of measuring these parameters.

The test findings also confirm the stability of operating an electronic control system (ECS) when the engine runs on all tested types of fuel. ECS operation moment, according to $P_{m e} 2$, is marked by a circle in Fig. 5. Figs 6 and 7 indicate parameters confirming the stability of operating engine ECS: charge air pressure $P_{K}$ and exhaust gas temperature $t_{t p i r}$ (measured by an infrared thermometer). Deviations from $P_{K}$ and $t_{t p i r}$ values taking approximate curves do not exceed $\pm 1 \div 1.5 \%$. Graphic dependences of changes in diesel engine parameters (Figs 4 and 5) show that the excess-air ratio $(\lambda)$ is the main parameter controlled by ECS specifying both energetic (overall indicated efficiency factor $\eta_{i}$, specific fuel consumption $b_{i}$ ) and ecological parameters $\left(\mathrm{NO}_{\mathrm{x}}, \mathrm{CO}, \mathrm{SM}, \mathrm{HC}\right)$ of the engine (Mollenhauer, Tschöke 2010; Lebedevas et al. 2007; Woschni 1988; Kruggel 1989).

The function of changes in the excess-air ratio considering the engine load (mean effective pressure $\left.P_{m e}\right)$ is similar to a hyperbolic function. Such type of $\lambda$ change is observed both in the engines without turbocharge and in those with a turbocompressor. When $P_{m e}$ increases at small loads, $\lambda$ decreases intensively, and changes in $\lambda$ considering the average and larger values of $P_{m e}$ slows down considerably.

Unlike in diesel engines without ECS, the minimal values of the excess-air ratio in the $1 \mathrm{Z}$ engine are not obtained in maximal capacity modes $\left(P_{\text {me max }}\right)$ when loading reaches approximately $P_{\text {me }} \approx 0.4 P_{\text {me } \max }$. ECS starts at this load, $\lambda$ starts increasing at $P_{m e} \approx 0.6 \div$ $0.7 P_{\text {me max }}$ and reaches 2.05 units or increases by $\sim 20 \%$ from the minimal value (see Fig. 2).

Respective changes in function $P_{m e}$ are characteristic of $\eta_{\mathrm{e}}$ (Fig. 4), SM (Fig. 3) and $\mathrm{NO}_{\mathrm{x}}$ emission (Fig. 5). Within the range of $P_{m e}$ from idle running to $0.35 P_{\text {me max }}\left(P_{m e}=0.45 \mathrm{MPa}\right)$, effective overall efficiency factor $\eta_{\mathrm{e}}$ is exponentially increasing (Fig. 4). Within the range of $P_{m e}$ of larger values $\left(P_{m e} \approx 0.65 \div 0.70 P_{\text {me max }}\right)$, according to dependence close to the parabola, $\eta_{e}$ increases up to 0.38 . ECS increases $\lambda$, simultaneously improves the supply of the engine cylinder with air and reduces the amount of partial combustion components $(\mathrm{SM}, \mathrm{CO}, \mathrm{HC})$ in exhaust gases as increased oxygen concentration in the combustion zone improves fuel combustion conditions (Wu, Leung 2011; Mollenhauer, Tschöke 2010).

The tests indicate that when the load is $0.35 P_{\text {me max }}$, the maximum obtained smokiness SM of exhaust gases is $\sim 30 \pm 5 \%$ according to Hartridge scale (HS); when $\lambda$ increases, SM emission intensively falls to $\sim 10 \%$ according to HS (Fig. 3) within the range of $0.4 \div 0.65 P_{\text {me max }}$.

Hydrocarbon (HC) emission reaches maximal values at $\sim 0.35 P_{\text {me max }}$ and stabilizes within the range of larger $P_{m e}$ values.

On the other hand, an increase in $\lambda\left(P_{m e} \geq\right.$ $\left.0.35 P_{\text {me max }}\right)$ influences the intensity of the fuel com- bustion process and raises $\mathrm{NO}_{\mathrm{x}}$ formation in the diesel cylinder and $\mathrm{NO}_{\mathrm{x}}$ emission in exhaust gases respectively (see Fig. 5). $\mathrm{NO}_{\mathrm{x}}$ emission reaches $\sim 180 \mathrm{ppm}$ at $P_{m e} \approx$ $0.35 P_{\text {me max }}$; when the load increases, $\mathrm{NO}_{\mathrm{X}}$ intensively increases and reaches $500 \mathrm{ppm}\left(P_{m e} \approx 0.6 P_{\text {me max }}\right)$ (Demirbas 2008; Kawtaradse 1989).

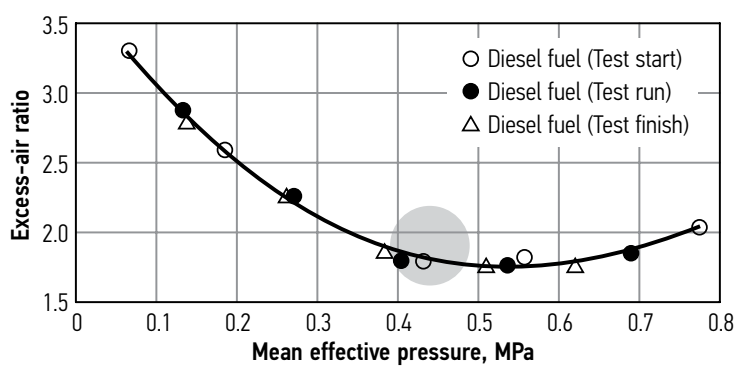

Fig. 2. The dependence of the excess-air ratio $\lambda$ of $1 \mathrm{Z}$ diesel engine on mean effective pressure $P_{m e}$ when the engine runs on diesel fuel

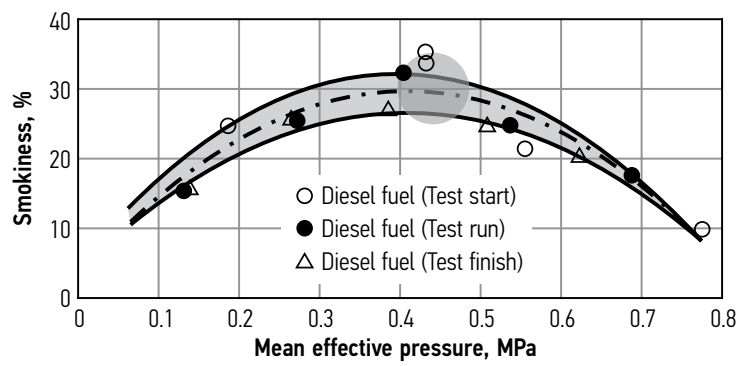

Fig. 3. The dependence of the smokiness SM of $1 \mathrm{Z}$ diesel engine on mean effective pressure $P_{m e}$ when the engine runs on diesel fuel

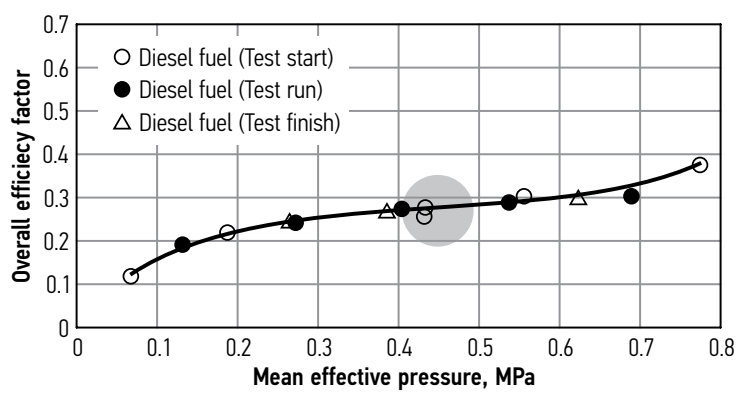

Fig. 4. The dependence of the overall efficiency factor $\eta_{e}$ of $1 Z$ diesel engine on mean effective pressure $P_{m e}$ when the engine runs on diesel fuel

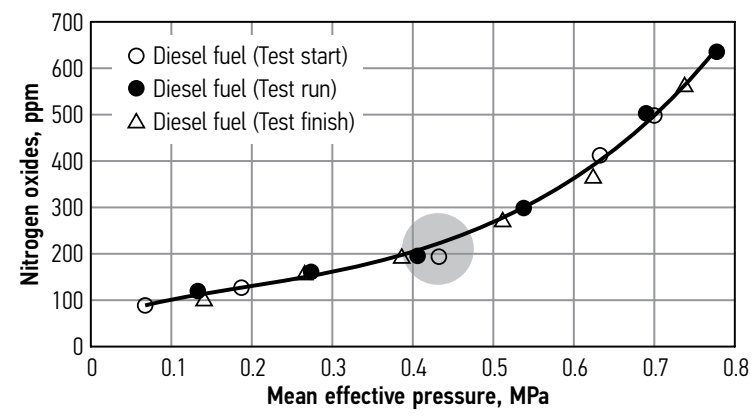

Fig. 5. The dependence of the nitrogen oxides $\left(\mathrm{NO}_{\mathrm{x}}\right)$ emission of $1 \mathrm{Z}$ diesel engine on mean effective pressure $P_{m e}$ when the engine runs on diesel fuel 


\section{Operation Parameters of the Biofuelled Engine}

The following two main aspects were analyzed when diesel fuel was replaced by biofuel B30:

- The stability of engine control, first of all, taking into account ECS regulated characteristics;

- Changes in the energetic and ecological parameters of the engine according to which a necessity to optimize the parameters of the FAME biofuelled engine is assessed.

Replacing diesel fuel by biofuels B30 (RME), B30 (WCME), B30 (SCME) had no impact on the parameters of ECS. When testing all types of fuels, identical approximate graphic dependences $P_{K}=f\left(P_{m e}\right)$ and $t_{\text {tpir }}=$ $f\left(P_{m e}\right)$ were obtained. This fact (see Figs 6 and 7) as well as the analysis of changes in the energetic and ecological parameters of the diesel engine given below show it is not necessary to optimize the control parameters of ECS when the diesel engine is fuelled with FAME B30.

One of the main energetic parameters $\eta_{\mathrm{e}}$ of diesel throughout the total load range compared to that of diesel fuel has remained the same (see Fig. 7). Taking into account the policy to increase the efficiency of power consumption implemented by the EU Parliament, this fact is considered as an important issue (Directive of the European Parliament... 2003). Technologies for using biofuels in vehicles should not reduce the efficiency

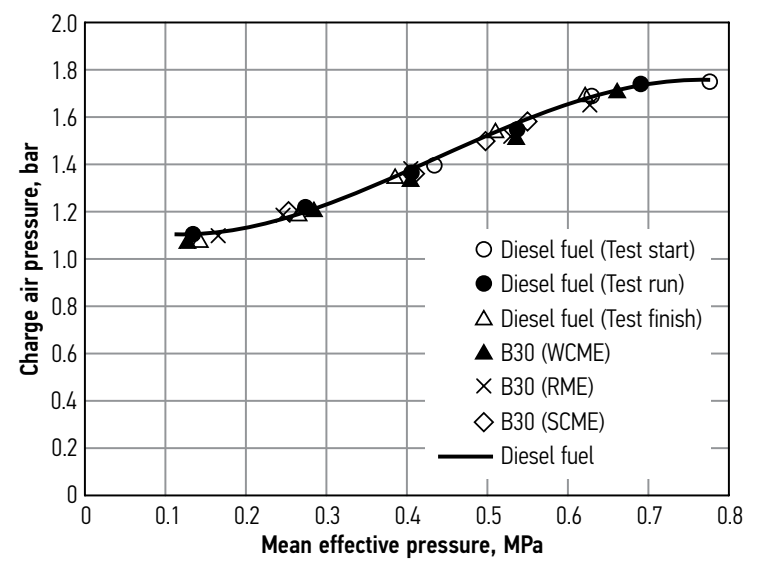

Fig. 6. The dependence of the charge air pressure $P_{K}$ of $1 Z$ diesel engine on mean effective pressure $P_{m e}$

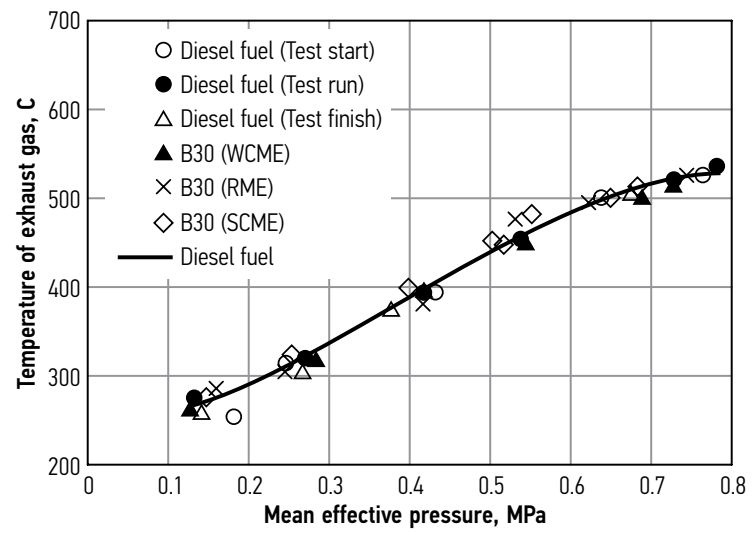

Fig. 7. The dependence of exhaust gas temperature $t_{\text {tpir }}$ of $1 \mathrm{Z}$ diesel engine on mean effective pressure $P_{m e}$ of power consumption. In terms of the engine power parameters, standard RME and new WCME and SCME biofuels are evaluated almost equally (see Fig. 8).

According to ecological diesel parameters, none of tested biofuels, including B30 (RME), B30 (WCME) and B30 (SCME) has any obvious advantage.

When evaluating the smokiness SM of exhaust gases, the obtained results of all tested B30 biofuels are similar (see Fig. 9). In terms of SM, no essential difference in the types of B30 biofuels was observed; however, compared to the use of diesel fuel, SM is $20 \div 25 \%$ lower throughout the total range of tests on $P_{m e}$.

According to $\mathrm{NO}_{\mathrm{x}}$ and $\mathrm{HC}$ emission, RME and camelina-based biofuel priorities distribute unevenly. In terms of $\mathrm{NO}_{\mathrm{x}}$ emission, biofuels show worse performance than diesel fuel. When using B30 (WCME) biofuels, $\mathrm{NO}_{\mathrm{x}}$ emission compared with that of diesel fuel practically does not change, and when using $\mathrm{B} 30$ (RME) and B30 (SCME) at $P_{m e} \geq 0.35 P_{m e}$ max, $\mathrm{NO}_{\mathrm{x}}$ emission increases, which reaches the maximal values of $\sim 15 \%$ at $P_{m e} \approx 0.5 \div 0.6 P_{\text {me max }}$ (see Fig. 10). When using B30 (WCME) biofuels, $\mathrm{HC}$ emission compared with diesel fuel remains the same. When the engine runs on B30 (RME) and B30 (SCME) biofuels, HC emission decreases by $15 \div 8 \%$ at $P_{m e} \geq 0.35 P_{\text {me max }}$ (see Fig. 11).

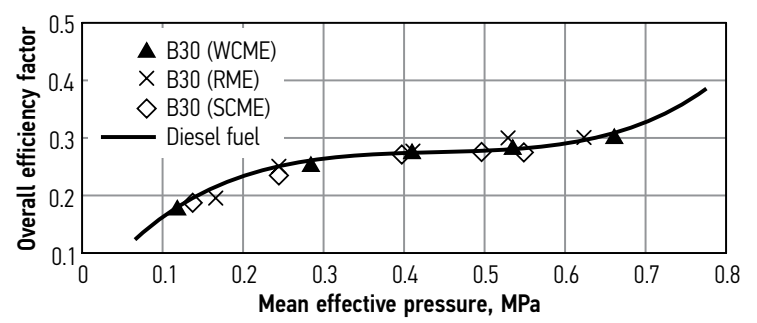

Fig. 8. The dependence of the overall efficiency factor $\eta_{e}$ of $1 \mathrm{Z}$ diesel engine on mean effective pressure $P_{m e}$

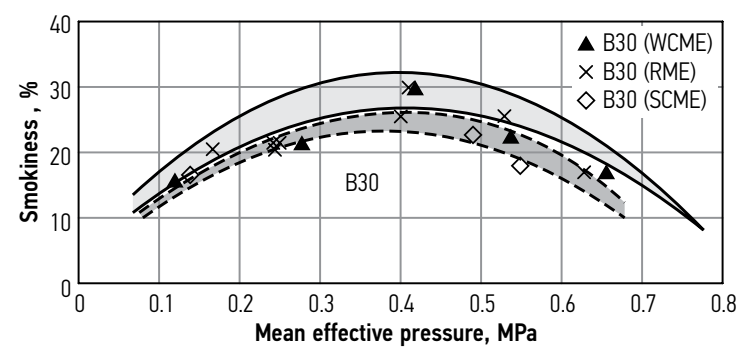

Fig. 9. The dependence of the smokiness SM of $1 \mathrm{Z}$ diesel engine on mean effective pressure $P_{m e}$

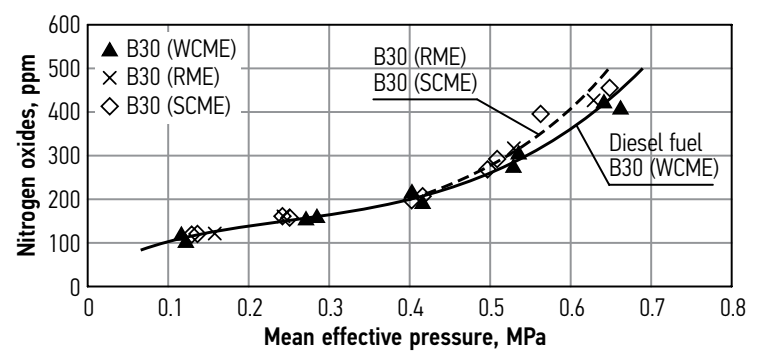

Fig. 10. The dependence of the nitrogen oxides $\left(\mathrm{NO}_{\mathrm{x}}\right)$ emission of $1 \mathrm{Z}$ diesel engine on mean effective pressure $P_{m e}$ 


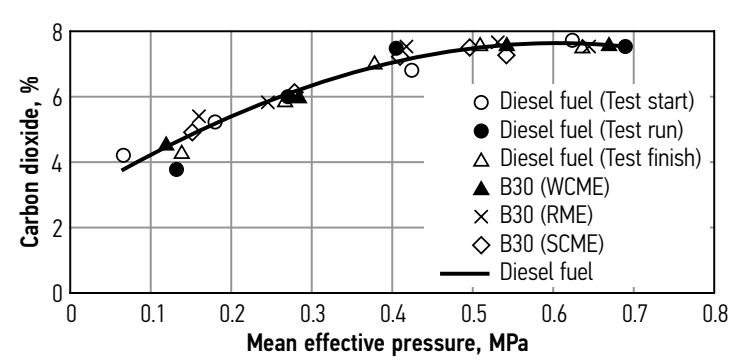

Fig. 11. The dependence of the $1 \mathrm{Z}$ hydrocarbon (HC) emission of the diesel engine on mean effective pressure $P_{m e}$

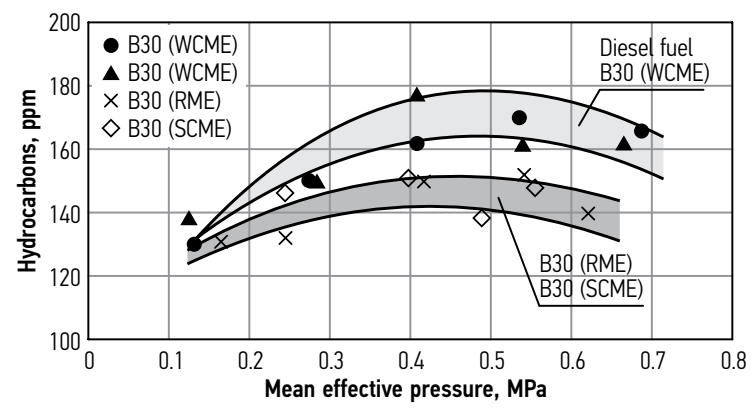

Fig. 12. The dependence of the carbon dioxide $\left(\mathrm{CO}_{2}\right)$ emission of $1 \mathrm{Z}$ diesel engine on mean effective pressure $P_{m e}$

The emission of carbon dioxide $\left(\mathrm{CO}_{2}\right)$ causing greenhouse gas effect throughout the total investigated range $P_{m e}$ does not depend on the tested types of biofuels (see Fig. 12). The obtained result was expectable because the main $\mathrm{CO}_{2}$ emission depends on the elementary amount of carbon in the fuel and excess-air ratio. The dependence $P_{m e}$ of an approximate curve of small loads within the range up to $P_{m e} \leq 0.35 P_{m e}$ max is close to the linear one. When the load increases, ECS stabilizes $\mathrm{CO}_{2}$ values. ECS increases parameter $\lambda$ and a relative amount of excess air in exhaust gases. As a result, $\mathrm{CO}_{2}$ emission expressed in the volumetric percent of exhaust gases reduces. When conducting comparative investigations into diesel fuels RME, WCME and SCME used in $1 \mathrm{Z}$ diesel engine, $\mathrm{CO}_{2}$ emission reaches $7.7 \%$ at the load of $P_{m e} \sim 0.5 \div 0.6 P_{m e}$ max. A reduction in $\mathrm{CO}_{2}$ emission is another significant advantage of diesel using ECS, including changes in the diesel engine operating on FAME biofuels.

In terms of $\mathrm{CO}_{2}$ emission caused by greenhouse gas effect, a more precise comparison of diesel fuel and B30 biofuels should be carried out taking into consideration the whole lifecycle of biofuel parameters. Based on the data (Thamsiriroj, Murphy 2011; Krohn, Fripp 2012) obtained throughout the total lifecycle of FAME biofuels (growing-production-transportation-use), $\mathrm{CO}_{2}$ emission, compared with diesel fuel, is approximately $20 \%$ lower than that found at the same emission from exhaust gases.

Changes in the ecological parameters obtained in the tests when diesel fuel is replaced by biofuels B30 (RME) and B30 (WCME and SCME) correlates well with comparative investigations into the same fuels in diesel engine VALMET DMG 320 (Lebedevas et al. 2010).

\section{Conclusions}

To enhance the efficiency of using power in the transport sector, changes in the diesel engine operating on biofuels B30 (RME, WCME, SCME) has been evaluated positively since the findings of conducted investigations have showed that the OEF (overall efficiency factor) of the diesel engine throughout the total range of the load remains similar to the use of diesel fuel and at the same time improves ecological parameters.

In terms of power properties, the new types of camelina-based methyl ester biofuels (WCME and SCME) are equal to standard RME biodiesel. The energetic parameters (first of all effective OEF) of diesel are practically equal throughout the total tested range of the load. If compared with B30 (RME), biofuel B30 (WCME) is characterized by $\sim 15 \%$ lower emission of the most harmful component $\mathrm{NO}_{\mathrm{X}}$ at the load of $\sim 65 \div 70 \%$ at the maximum. Biofuels B30 (RME), B30 (WCME) and B30 (SCME) are characterized by the same smokiness of engine exhaust gases, which makes approximately $20 \%$ lower compared with diesel fuel throughout the whole range of the engine load. If compared with the use of diesel fuel, greenhouse gas $\mathrm{CO}_{2}$ emission contained in exhaust gases remains the same.

With reference to the findings of the conducted tests, it is accepted that the engine control parameters cannot be modified when $1 \mathrm{Z}$ diesel engine and models similar to it, according to their structure containing the ECS and recirculation of exhaust gases and taking into consideration ecological and energetic parameters, are powered by B30 FAME (RME and camelina sativa) biofuels.

\section{Acknowledgements}

The authors of the article express their gratitude to Lithuanian Agency for Science, Innovation and Technology for their kind assistance in organizing and conducting investigations into the use of camelina sativa biofuels in the transport sector.

\section{References}

Demirbas, A. 2008. Biodiesel: A Realistic Fuel Alternative for Diesel engines. 1st edition. Springer. 218 p.

Directive of the European Parliament and of the Council on Energy End-Use Efficiency and Energy Services (and Repealing Council Directive 93/76/EEC) COM (2003) 739 Final, C6-0298/2005-2003/0300 (COD)).

EN 590:2004. Automotive Fuels. Diesel. Requirements and Test Methods.

EN 14214:2003. Automotive Fuels. Fatty Acid Methyl Esters (FAME) for Diesel Engines. Requirements and Test Methods.

European Commission 2011. White Paper: Roadmap to a Single European Transport Area - Towards a Competitive and Resource Efficient Transport System. COM(2011) 144 final. 28.3.2011, Brussels. Available from Internet: http://eur-lex. europa.eu/LexUriServ/LexUriServ.do?uri=CELEX:52011D C0144:EN:NOT

Fargione, J.; Hill, J.; Tilman, D.; Polasky, S.; Hawthorne, P. 2008. Land clearing and the biofuel carbon debt, Science 319: 1235-1238. http://dx.doi.org/10.1126/science.1152747 
Fröhlich, A.; Rice, B. 2005. Evaluation of Camelina sativa oil as a feedstock for biodiesel production, Industrial Crops and Products 21(1): 25-31. http://dx.doi.org/10.1016/j.indcrop.2003.12.004

Goldemberg, J.; Guardabassi, P. 2009. Are biofuels a feasible option?, Energy Policy 37(1): 10-14. http://dx.doi.org/10.1016/j.enpol.2008.08.031

Kawtaradse, R. 1989. Mathematisches Modell des komplexen Wärmeaustausches - Konvektion und Strahlung - im Brennraum des Dieselmotors, Technische Mechanik 10(3): 175-177 (in German).

Koh, L. P.; Ghazoul, J. 2008. Biofuels, biodiversity, and people: Understanding the conflicts and finding opportunities, Biological Conservation 141(10): 2450-2460. http://dx.doi.org/10.1016/j.biocon.2008.08.005

Krohn, B. J.; Fripp, M. 2012. A life cycle assessment of biodiesel derived from the 'niche filling' energy crop camelina in the USA, Applied Energy 92: 92-98. http://dx.doi.org/10.1016/j.apenergy.2011.10.025

Kruggel, O. 1989. Progress in the combustion technology of high performance diesel engines toward reduction of exhaust emissions without reduction of operation economy, in Proceedings of Baden-Wurttemberg Technology Conference. $14 \mathrm{p}$.

Lebedevas, S.; Lebedeva, G.; Makarevičienè, V.; Kazanceva, I.; Kazancev, K. 2010. Analysis of the ecological parameters of the diesel engine powered with biodiesel fuel containing methyl esters from Camelina sativa oil, Transport 25(1): 22-28. http://dx.doi.org/10.3846/transport.2010.04

Lebedevas, S.; Vaicekauskas, A.; Suškov, P. 2007. Presumptions of effective operation of diesel engines running on RME biodiesel. Research on kinetics of combustion of RME biodiesel, Transport 22(2): 126-133.

LST EN 590:2009+A1:2010. Automobiliniai degalai. Dyzelinas. Reikalavimai ir tyrimo metodai [Automotive Fuels - Diesel - Requirements and Test Methods].

LST EN 14214:2003. Automobiliniai degalai. Riebalu rūgščiu metilesteriai (RRME), skirti dyzeliniams varikliams. Reikalavimai ir tyrimy metodai [Automotive Fuels. Fatty Acid Methyl Esters (FAME) for Diesel Engines. Requirements and Test Methods].

Mollenhauer, K.; Tschöke, H. 2010. Handbook of Diesel Engines. 1st edition. Springer. 648 p.

Moser, B. R.; Vaughn, S. F. 2010. Evaluation of alkyl esters from Camelina sativa oil as biodiesel and as blend components in ultra low-sulfur diesel fuel, Bioresource Technology 101(2): 646-653. http://dx.doi.org/10.1016/j.biortech.2009.08.054

Searchinger, T.; Heimlich, R.; Houghton, R. A.; Dong, F.; Elobeid, A.; Fabiosa, J.; Tokgoz, S.; Hayes, D.; Yu, T.-H. 2008. Use of U.S. croplands for biofuels increases greenhouse gases through emissions from land-use change, Science 319: 1238-1240. http://dx.doi.org/10.1126/science.1151861

Thamsiriroj, T.; Murphy, J. D. 2011. The impact of the life cycle analysis methodology on whether biodiesel produced from residues can meet the EU sustainability criteria for biofuel facilities constructed after 2017, Renewable Energy 36(1): 50-63. http://dx.doi.org/10.1016/j.renene.2010.05.018

Woschni, G. 1988. Verbrennungsmotoren. TU München. 303 S. (in German).

Wu, X.; Leung, D. Y. C. 2011. Optimization of biodiesel production from Camelina oil using orthogonal experiment, Applied Energy 88(11): 3615-3624.

http://dx.doi.org/10.1016/j.apenergy.2011.04.041 